\title{
Selection and Characterization of Bacteriocin-Producing Lactobacillus sp. AP 116 from the Intestine of Pig for Potential Probiotics
}

\author{
Myeong-Su Shin ${ }^{1,2}$, Hyun-Jong Choi ${ }^{1}$, Kyeong-Hyeon Jeong ${ }^{2}$, Jong-Cheol Lim², \\ Kyeong-Su Kim², and Wan-Kyu Lee ${ }^{1 *}$ \\ ${ }^{1}$ College of Veterinary Medicine, Chungbuk National University, Cheongju 361-763, Korea \\ ${ }^{2}$ Korea Bio Science Research Institute of Organic Bio Tech Co. Ltd., Jincheon 365-861, Korea
}

\begin{abstract}
The purpose of this study was to isolate bacteriocin-producing bacteria with antagonistic activities against pathogens from the intestines of pigs for probiotic use. Lactobacillus sp. AP 116 possessing antimicrobial property was selected from a total of 500 isolates. The AP 116 strain showed a relatively broad spectrum of inhibitory activity against Listeria monocytogenes, Clostridium perfringens, Pediococcus dextrinicus, and Enterococcus strains using the spot-on-lawn method. Bacteriocin activity remained unchanged after $15 \mathrm{~min}$ of heat treatment at $121^{\circ} \mathrm{C}$ and exposure to organic solvents; however, it diminished after treatment with proteolytic enzymes. Maximum production of bacteriocin occurred at $34^{\circ} \mathrm{C}$ when a $\mathrm{pH}$ of $6.0 \mathrm{was}$ maintained throughout the culture during fermentation. According to a tricine SDS-PAGE analysis, the molecular weight of the bacteriocin was approximately $5 \mathrm{kDa}$. The isolate tolerated bile salts and low $\mathrm{pH}$, and also induced nitric oxide (NO) in mouse peritoneal macrophages. Bacteriocin and bacteriocin-producing bacteria, such as Lactobacillus sp. AP 116, could be potential candidates for use as probiotics as an alternative to antibiotics in the pig industry.
\end{abstract}

Key words: antimicrobial activity, bacteriocin, probiotics, alternatives, Lactobacillus

\section{Introduction}

Antibiotics have been widely used at subtherapeutic levels as an animal growth promoter and against pathogenic bacteria in gastrointestinal systems for more than 50 years (Dibner and Richards, 2005). Subtherapeutic antibiotics have succeeded in improving growth and feed conversion in poultry and swine production. However, resistant bacterial populations, residual antibiotics in animal meat, and the increasing consumer demand for organic production have increased interest in searching for alternatives to antibiotics in recent years.

Among these alternatives, probiotics have received much attention as the most promising substitute to in-feed antibiotics and for improving animal productivity (Byun et al., 2000; Joerger, 2003; Roselli et al., 2005). Probiotic bacteria (primarily lactic acid bacteria, LAB) used as feed additives should originate preferably from the target ani-

\footnotetext{
*Corresponding author: Wan-Kyu Lee, College of Veterinary Medicine and Research Institute of Veterinary Medicine, Chungbuk National University, Cheongju 361-763, Korea. Tel: 82-43-261-2960, Fax: 82-43-267-3150, E-mail: wklee@cbu. ac. $\mathrm{kr}$
}

mal microflora (Kosin and Rakshit, 2006). Probiotics are mostly anticipated to function as a growth inhibitor of pathogenic bacteria in animal intestines due to their abilities to modulate the host's immune system and/or directly affect infectious microorganisms by producing antimicrobial agents including organic acids, hydrogen peroxide, and bacteriocins (Oelschlaeger, 2010). Macrophages play the central role in initiating the first defense line of host immunity. Activated macrophages may regulate immunity by enhancing secretion of proinflammatory cytokines (interleukin-6, tumor necrosis factor- $\alpha$ ) and nitric oxide (NO). NO is a short-lived mediator that has antimicrobial actions against various phathogens via its cytotoxic or cytostatic effects (Snyder and Bredt, 1992).

Many Gram-positive and Gram-negative bacteria produce bacteriocins, which are ribosomally-synthesized peptides or proteins with antimicrobial properties that often target bacterial species that are closely related to the producer strain. Bacteriocins produced by LAB have received particular attention in recent years due to their potential application in the food industry as natural preservatives against food-borne pathogens (Cleveland et al., 2001). Food-borne pathogens, such as Listeria monocytogenes, Clostridium perfringens, and Salmonella sp., are com- 
monly found in animal intestines (Jung et al., 2003; Kim et al., 2006). They are frequently associated with swine diseases and may contaminate meat during pork processing (Thévenot et al., 2006; Warriner et al., 2002). Therefore, to prevent gastrointestinal colonization of livestock by foodborne pathogens, the use of bacteriocin-producing bacteria in animal feed is recommended (Callaway et al., 2004; Gillor et al., 2004). Bacteriocin production by intestinal LAB may play an important role in their survival, thereby enabling them to compete in an environment with an abundance and diversity of microorganisms (Damelin et al., 1995; Du Toit et al., 2000). Despite their potential as an alternative to antibiotics, few studies have investigated the use of bacteriocin-producing intestinal LAB in the animal industry (Diez-Gonzalez, 2007; Strompfová et al., 2006).

The purpose of this study was to isolate bacteriocinproducing bacteria with antagonistic activities against pathogens from the intestines of pig and to develop a potential candidate for probiotic use in the pig industry as an alternative to antibiotics. We describe the selection process and partial characteristics of Lactobacillus sp. AP 116 and the bacteriocin that shows inhibitory activity against several Gram-positive bacteria.

\section{Materials and Methods}

\section{Bacterial strains and culture conditions}

Lactobacillus sp. AP 116 was isolated from the intestines of pig and maintained at $-70^{\circ} \mathrm{C}$ in lactobacilli MRS broth (Difco Laboratories, Detroit, USA) containing 50\% $(\mathrm{v} / \mathrm{v})$ glycerol. Indicator organisms were obtained from the Korean Collection for Type Culture (KCTC) or Korean Culture Center of Microorganisms (KCCM), and propagated in appropriate media as indicated in Table 1.

\section{Isolation of LAB}

Intestine samples (obtained from a slaughterhouse) were homogenized and serially diluted ten-fold with saline solution, plated on MRS, and incubated at $37^{\circ} \mathrm{C}$ for 2 to 3 $\mathrm{d}$. The antimicrobial substances producing bacteria were screened by a modification of the deferred method. For the modified deferred method, approximately five colonies per sample were randomly selected with sterilized toothpicks and inoculated into $1 \mathrm{~mL}$ of MRS broth in a microcentrifuge tube. After isolates were grown for $2 \mathrm{~d}$ at $37^{\circ} \mathrm{C}, 10 \mu \mathrm{L}$ of culture broth were spotted on MRS agar and dried for $1 \mathrm{~h}$. The plate was overlaid with $0.7 \%$ MRS or BHI agar (Difco Laboratories, USA) seeded with an overnight culture of the following indicator strains (approximately $5.0 \times 10^{6} \mathrm{CFU} / \mathrm{mL}$ each): Escherichia coli KCTC 1467, Salmonella Typhimurium KCTC 2515, Staphylococcus aureus KCTC 1621, Listeria monocytogenes KCTC 3569, and Lactobacillus sake KCCM 40264. After incubation for $24 \mathrm{~h}$ at the appropriate temperature, colonies with clear inhibition zones were further examined for bacteriocin production.

\section{Detection of bacteriocin-producing LAB by the spot-on-lawn method}

Cells were pelleted by centrifugation $(10,000 \mathrm{~g}$ for 15 min). The supernatant was adjusted to $\mathrm{pH} 6.5$ with $10 \mathrm{~N}$ $\mathrm{NaOH}$ and filtered through $0.2-\mu \mathrm{m}$ pore size membrane filters and used to detect antagonistic activity against indicator organisms according to the spot-on-lawn method (Mayr-Harting et al., 1972). The supernatant was serially diluted, and $10-\mu \mathrm{L}$ samples were spotted onto $0.7 \%$ MRS or BHI agar seeded with an overnight culture of an indicator strain. After incubation for $24 \mathrm{~h}$ at the appropriate temperature, plates were checked for inhibition zones. Bacteriocin activity was expressed in terms of arbitrary units per $\mathrm{mL}(\mathrm{AU} / \mathrm{mL})$, which was defined as the highest dilution showing a definite inhibition of the indicator lawn.

\section{Identification of bacterial strain}

Morphological and biochemical properties of the samples were examined to identify bacteriocin-producing microorganisms (Holt et al., 1994). We assessed Gram staining, morphology, catalase activity, salt tolerance, gas production, growth temperature range, and biochemical carbohydrate fermentation patterns using an API $50 \mathrm{CHL}$ kit (Biomérieux, France). The 16S rDNA gene was sequenced using the Big Dye terminator cycle sequencing kit (Applied BioSystems, USA) and an automated DNA sequencing system (Applied Biosystems model 3730XL, USA). This sequence was aligned with the 16S rRNA gene sequence of $\mathrm{LAB}$ and other related taxa to compare levels of similarity.

\section{Bacteriocin extraction by pH-mediated adsorption and desorption}

Bacteriocin extraction from Lactobacillus sp. AP 116 was performed using a modified method of Yang et al. (1992). After AP 116 was grown at $37^{\circ} \mathrm{C}$ in $1 \mathrm{~L}$ of MRS broth for $16 \mathrm{~h}$, the culture was heated to $80^{\circ} \mathrm{C}$ for $30 \mathrm{~min}$ to kill the cells and inactivate proteolytic enzymes. Subsequently, the $\mathrm{pH}$ of the culture was adjusted to 6.5 with 
$5 \mathrm{~N} \mathrm{NaOH}$ and was stirred for $30 \mathrm{~min}$ at room temperature to allow cellular adsorption of the bacteriocin. Bacterial cells were collected by centrifugation at 4,000 g for $30 \mathrm{~min}$ and washed twice with $5 \mathrm{mM}$ sodium phosphate buffer (pH 6.5). Cells were resuspended in $50 \mathrm{ml}$ of 100 $\mathrm{mM} \mathrm{NaCl}$, adjusted to $\mathrm{pH} 2.0$ with $5 \%$ phosphoric acid, and then gently stirred at $4^{\circ} \mathrm{C}$ for $2 \mathrm{~h}$ to desorb the bacteriocin from the cells. Cell suspensions were then centrifuged at 4,000 $\mathrm{g}$ for $30 \mathrm{~min}$. Supernatants were dialyzed using a membrane with a $1 \mathrm{kDa}$ cutoff (Spectrum Medical Inc., Los Angeles, CA, USA) for $24 \mathrm{~h}$ at $4^{\circ} \mathrm{C}$ and then freeze-dried. Freeze-dried material was resuspended in distilled water and used as crude bacteriocin in the following experiments.

\section{Effects of heat, pH, enzymes, and organic solvents} on bacteriocin activity

Crude bacteriocin was heated for $30 \mathrm{~min}$ at $60^{\circ} \mathrm{C}$ or $90^{\circ} \mathrm{C}$, or at $121^{\circ} \mathrm{C}$ for $15 \mathrm{~min}$. Residual bacteriocin activity was subsequently determined by the spot-on-lawn assay. To study the effects of $\mathrm{pH}$ on antimicrobial stability, the crude bacteriocin was adjusted to a $\mathrm{pH}$ of 2-10 with either $1 \mathrm{~N} \mathrm{HCl}$ or $1 \mathrm{~N} \mathrm{NaOH}$ and incubated at $30^{\circ} \mathrm{C}$ for $1 \mathrm{~h}$. The bacteriocin was also treated with various enzymes in a final concentration of $1 \mathrm{mg} / \mathrm{mL}$. All enzymes (Proteinase $\mathrm{K}$, protease type XIV, pepsin, trypsin, $\alpha$-amylase, $\beta$-amylase, and catalase) were dissolved in buffers recommended by the manufacturer (Sigma Chemical Co., USA). The mixture was then incubated at $30^{\circ} \mathrm{C}$ for $1 \mathrm{~h}$ and heated at $80^{\circ} \mathrm{C}$ for $10 \mathrm{~min}$ to inactivate the enzymes. The bacteriocin was also treated with $50 \%$ organic solvents such as ethanol, methanol, chloroform, acetone, acetonitrile, hexane, and cyclohexane. Solvent-treated samples were incubated at $37^{\circ} \mathrm{C}$ for $1 \mathrm{~h}$.

\section{Determination of the molecular weight of the anti- microbial compound}

Electrophoresis of the crude bacteriocin was performed on a $16.5 \%$ tricine-SDS polyacrylamide gel. One-half of the gel was stained with $0.1 \%$ Coomassie brilliant blue G250 (Bio-Rad, USA) and destained using a methanolacetic acid-water (3:1:6) solution. The other half of the gel was washed three times in sterile water for $30 \mathrm{~min}$ and overlaid with BHI soft agar $(0.7 \%)$ inoculated with fresh cultures of $L$. monocytogenes. The molecular weight of the bacteriocin was estimated by comparing molecular mass markers.

\section{Activity against $L$. monocytogenes}

Cells of L. monocytogenes at log-phase growth were centrifuged, washed, and resuspended in $10 \mathrm{ml}$ of $50 \mathrm{mM}$ phosphate buffer ( $\mathrm{pH}$ 6.8) to a final concentration of 2.0 $\times 10^{8} \mathrm{CFU} / \mathrm{mL}$. Crude bacteriocin was added at concentrations of 200, 400, and $800 \mathrm{AU} / \mathrm{mL}$. Viable cells were counted from aliquots taken at predetermined time intervals.

\section{Culture conditions for bacteriocin production}

The effects of temperature and $\mathrm{pH}$ on bacteriocin production were studied. AP 116 was incubated in MRS broth in a 5-L jar fermenter (FERMENTEC Co., Korea). Temperature and $\mathrm{pH}$ were maintained at $30^{\circ} \mathrm{C}, 34^{\circ} \mathrm{C}$, and $37^{\circ} \mathrm{C}$, and at 5.0, 6.0, and 7.0 with $10 \mathrm{~N} \mathrm{NaOH}$, respectively. The culture was agitated at $50 \mathrm{rpm}$. Cell counts and bacteriocin activity were measured at $2 \mathrm{~h}$ intervals. Viable cell counts were determined by the pour plate method on MRS agar, and bacteriocin activity was tested by the spot-on-lawn assay.

\section{Nitric oxide assay}

Mouse peritoneal macrophages were isolated from C57BL/6 mouse according to the method of Zhang et al. (2008). Peritoneal macrophages $\left(5 \times 10^{5}\right.$ cells/well) were triplicately cultured in a RPMI 1640 medium (Sigma, USA) supplemented with $10 \%(\mathrm{v} / \mathrm{v})$ FBS (Invitrogen, USA) along with, $100 \mathrm{mg} / \mathrm{mL}$ streptomycin and $100 \mathrm{U} /$ $\mathrm{mL}$ penicillin (Invitrogen, USA) and heat-killed probiotics $\left(100 \mu \mathrm{L}\right.$ containing $5 \times 10^{7} \mathrm{CFU} / \mathrm{mL}$ of AP 116 or Lactobacillus rhamnosus $\mathrm{GG}$ ) were added to the wells. PBS was only added to wells as a negative control, and LPS (100 ng/mL; Sigma, USA) was added in PBS-containing wells as a positive control. After $24 \mathrm{~h}$, the culture supernatants were collected and the concentrations of $\mathrm{NO}$ in the supernatants were determined. NO levels of macrophages were measured using Griess reagent (Promega, USA). Briefly, $50 \mathrm{~mL}$ of macrophage culture supernatant were mixed (in triplicate) with an equal volume of $1 \%$ sulfanilamide in $5 \%$ phosphoric acid and $0.1 \% \mathrm{~N}-1-$ Naphylethylenediamine dihydrochloride at room temperature for $10 \mathrm{~min}$ in the dark. Absorbance was then measured at $540 \mathrm{~nm}$ by using a microplate reader (Molecular Devices, USA). The production levels of NO were calculated from a standard curve for a nitrite standard (0-100 $\mu \mathrm{M}$ sodium nitrite).

\section{Survival and growth at low $\mathrm{pH}$ and in the presence of bile salts}

Acid and bile salt tolerance were performed as describ- 
ed by Shin et al. (2008). To test acid tolerance, overnight cultures in MRS medium of selected strain were harvested at $4000 \mathrm{~g}$ for $10 \mathrm{~min}$ at $4^{\circ} \mathrm{C}$ and washed twice with $50 \mathrm{mM}$ phosphate buffer and resuspended in $20 \mathrm{ml}$ of the same buffer. The final $\mathrm{pH}$ was adjusted to $2.0,2.5,3.0$, and 7.0. The suspensions were incubated at $37^{\circ} \mathrm{C}$ for $2 \mathrm{~h}$, and the viable cell counts were determined by the pour plate method on MRS agar. Bile tolerance was determined by spreading the cells on MRS agar plates containing oxgall bile $(0 \%, 0.05 \%, 0.1 \%, 0.3 \%$, and $0.5 \%$, respectively). Plates were incubated at $37^{\circ} \mathrm{C}$ for $48 \mathrm{~h}$, and the viable cell counts were determined.

\section{Statistical analysis}

The data were statistically analyzed using the software package SPSS 13.0 Window Program (SPSS Inc., USA). A one-way analysis of variance (ANOVA) with Duncan's multiple range test was used to distinguish treatment mean differences. Values of $p<0.05$ were considered significant.

\section{Results and Discussion}

\section{Screening and identification of bacteriocin-produc- ing $\mathbf{L A B}$}

More than $60 \%$ of the approximately 500 strains isolated from the intestines of pig showed inhibitory activity to at least one of the five indicators tested in the first screening step. The isolates that showed a larger inhibition zone (greater than $15 \mathrm{~mm}$ ) were further tested for their antimicrobial activities. Cell-free supernatants were neutralized with $\mathrm{NaOH}$ to eliminate the effect of organic acids; subsequently, the inhibition test against indicator organisms was performed by the spot-on-lawn method. Five strains (AP 116, HN 52, HN 92, HN 98, and HN 235) were finally selected as antimicrobial agent-producing bacteria. AP 116 showed the largest zone of inhibition against $L$. monocytogenes and was therefore selected for further characterization. This strain was characterized as a Gram-positive, catalase-negative, and facultative anaerobic rod-shaped bacterium (Fig. 1). Based on these characteristics and on the API test results (carbohydrate fermentation test), the isolate was classified as Lactobacillus acidophilus AP 116 (data not shown). The 16S rDNA sequence of AP 116 showed 99\% similarity with Lactobacillus sp. 52A and low similarity (96\%) with L. agilis; thus, further work is required to determine species identification.

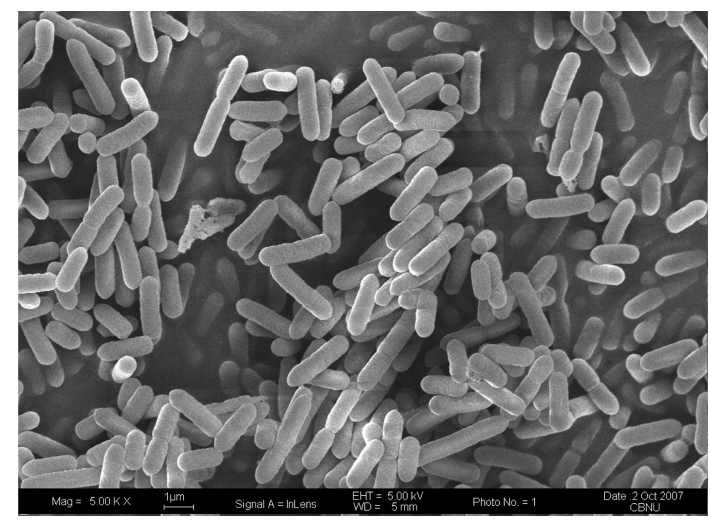

Fig. 1. Scanning electron micrograph of Lactobacillus sp. AP 116.

\section{Spectrum of antimicrobial activity}

Both culture and crude bacteriocin extracted by $\mathrm{pH}-$ mediated adsorption method were tested for their antimicrobial activities against various Gram-positive and Gramnegative bacteria using the modified deferred and spoton-lawn methods (Table 1). AP 116 showed a broad spectrum of inhibitory activity against most of the pathogenic and non-pathogenic bacteria tested by the modified deferred method. The inhibitory activity of AP 116 against Gramnegative strains in the modified deferred analysis could be attributed primarily by the accumulation of organic acids. It also demonstrated a relatively broad spectrum of activity against all Enterococcus strains, Listeria, Pediococcus dextrinicus, and $\mathrm{Cl}$. perfringens tested by the spoton-lawn method. The bacteriocin was inactive against Gram-negative bacteria, E. coli, and Salmonella Typhimurium. However, the bacteriocin had a high anti-listeria activity compared to other sensitive strains and a low inhibitory activity against $\mathrm{Cl}$. perfringens. The spectrum of anti-listerial activity of AP 116 bacteriocin was similar to that reported for other Class IIa bacteriocins, especially pediocin PA-1 (Gonzalez and Kunka, 1987). Growth of bacteriocin-producing bacteria may have a direct affect on reducing existing populations of food-borne pathogens. Long-term colonization with bacteriocin-producing bacteria may also prevent further re-introduction of pathogenic bacteria (Diez-Gonzalez, 2007). Therefore, AP 116, which showed antagonistic activity against pathogens, could be used in controlling enteric pathogenic bacteria in pig gastrointestinal systems and further reduce contamination in swine processing.

Effects of enzymes, heat, $\mathrm{pH}$, and organic solvents on bacteriocin activity

Antimicrobial activity was completely inactivated by 
Table 1. Antimicrobial spectrum of bacteriocin produced by Lactobacillus sp. AP 116

\begin{tabular}{|c|c|c|c|}
\hline Indicator strains & Medium & Modified deferred method & Spot-on-lawn method \\
\hline Bacillus cereus KCTC 1012 & $\mathrm{BHI}$ & + & - \\
\hline Clostridium perfringens KCTC 3269 & BHI & + & $200 \mathrm{AU} / \mathrm{mL}$ \\
\hline Escherichia coli KCTC 1467 & BHI & + & - \\
\hline Escherichia coli KCTC 11682 & BHI & + & - \\
\hline Enterobacter aerogenes KCTC 2190 & BHI & + & - \\
\hline Enterococcus durans KCTC 3121 & MRS & + & $51,200 \mathrm{AU} / \mathrm{mL}$ \\
\hline Enterococcus faecalis KCTC 2011 & MRS & + & $25,600 \mathrm{AU} / \mathrm{mL}$ \\
\hline Enterococcus faecalis KCTC 3206 & MRS & + & $25,600 \mathrm{AU} / \mathrm{mL}$ \\
\hline Enterococcus faecium КCTC 3513 & MRS & + & $51,200 \mathrm{AU} / \mathrm{mL}$ \\
\hline Klebsiella pneumoniae КСТC 2208 & BHI & + & - \\
\hline Lactobacillus acidophilus KCTC 3111 & MRS & + & - \\
\hline Lactobacillus casei KCTC 3109 & MRS & - & - \\
\hline Lactobacillus delbrueckii КСТC 1047 & MRS & - & - \\
\hline Lactobacillus fermentum KCТC 3112 & MRS & - & - \\
\hline Lactobacillus plantarum KCTC 3108 & MRS & - & - \\
\hline Leuconostoc mesenteroides KCTC 3505 & MRS & - & - \\
\hline Listeria monocytogenes KCTC 3569 & BHI & + & $204,800 \mathrm{AU} / \mathrm{mL}$ \\
\hline Listeria monocytogenes KCТC 3710 & BHI & + & $204,800 \mathrm{AU} / \mathrm{mL}$ \\
\hline Listeria innocua КСТС 3586 & BHI & + & $204,800 \mathrm{AU} / \mathrm{mL}$ \\
\hline Pediococcus acidilactici KCTC 1626 & MRS & + & - \\
\hline Pediococcus dextrinicus КСТС 3506 & MRS & + & $51,200 \mathrm{AU} / \mathrm{mL}$ \\
\hline Proteus mirabillis KCTC 2566 & BHI & + & - \\
\hline Pseudomonas aeruginosa KCTC 1750 & BHI & + & - \\
\hline Salmonella Typhimurium KCTC 2515 & $\mathrm{BHI}$ & + & - \\
\hline Staphylococcus aureus KCTC 1621 & BHI & + & - \\
\hline Staphylococcus aureus KCTC 1916 & $\mathrm{BHI}$ & + & - \\
\hline Staphylococcus epidermidis KCTC 1917 & $\mathrm{BHI}$ & + & - \\
\hline
\end{tabular}

- , no inhibition zone; +, clear inhibition zone

treatment with Proteinase K, protease type XIV, and trypsin. However, this did not occur with pepsin, $\alpha$-amylase, $\beta$ amylase, and catalase (Table 2). The AP 116 bacteriocin was highly thermostable, maintaining antimicrobial activity even after treatment at $121^{\circ} \mathrm{C}$ for $15 \mathrm{~min}$. Bacteriocin activity was also stable from $\mathrm{pH} 2$ to 10 for $1 \mathrm{~h}$. It was mostly unaffected by exposure to the organic solvents at $50 \%$ concentrations. Antimicrobial activity was sensitive to three proteolytic enzymes tested, indicating that the inhibitory agent produced by Lactobacillus sp. AP 116 was proteinaceous in structure. There was no loss of antimicrobial activity following treatment with amylase, organic solvents, and catalase due to the possible absence of carbohydrate moieties and hydrogen peroxide in its composition. Similar results have been found in previous studies (Bhunia et al., 1991; Gonzalez and Kunka, 1987; Shin et al., 2008). These results suggest that the inhibitory compound is a bacteriocin.

\section{Bacteriocin extraction and determination of molec- ular weight}

A brown, sticky contaminant was detected in pellets after treatment of ammonium sulfate saturation. Due to the presence of this substance, the next step in the purification of bacteriocin was difficult (data not shown). However, a clean and white freeze-dried powder (crude bacteriocin) was obtained by the $\mathrm{pH}$-mediated adsorption and desorption method. To estimate the molecular weight, the crude bacteriocin was subjected to tricine SDS-PAGE. A single band appeared at approximately $5 \mathrm{kDa}$. When the duplicate gel was tested for antimicrobial activity against L. monocytogenes as an indicator, an inhibition zone was detected (Fig. 2). Further studies are necessary to purify and characterize the bacteriocin.

\section{Activity against $L$. monocytogenes}

To determine whether the bacteriocin produced by Lactobacillus sp. AP 116 was bactericidal or bacteristatic against sensitive strains, crude bacteriocin was added at different concentrations to L. monocytogenes suspended in $50 \mathrm{mM}$ phosphate buffer. The number of viable bacterial cells decreased rapidly after the first $30 \mathrm{~min}$ and then 
Table 2. Effects of enzymes, heat, pH, and organic solvents on the activity of bacteriocin partially purified from Lactobacillus sp. AP 116

\begin{tabular}{|c|c|c|}
\hline \multicolumn{2}{|c|}{ Treatment } & $\begin{array}{l}\text { Bacteriocin activity } \\
(\mathrm{AU} / \mathrm{mL})\end{array}$ \\
\hline \multicolumn{2}{|c|}{ Control } & 3,200 \\
\hline \multirow{7}{*}{ Enzymes } & Proteinase $\mathrm{K}$ & 0 \\
\hline & Protease XIV & 0 \\
\hline & Pepsin & 3,200 \\
\hline & Trypsin & 0 \\
\hline & $\alpha$-Amylase & 3,200 \\
\hline & $\beta$-Amylase & 3,200 \\
\hline & Catalase & 3,200 \\
\hline \multirow{3}{*}{ Heating } & $60^{\circ} \mathrm{C}, 30 \mathrm{~min}$ & 3,200 \\
\hline & $95^{\circ} \mathrm{C}, 30 \mathrm{~min}$ & 3,200 \\
\hline & $121^{\circ} \mathrm{C}, 15 \mathrm{~min}$ & 3,200 \\
\hline \multirow{9}{*}{$\mathrm{pH}$} & pH 2.0 & 3,200 \\
\hline & $\mathrm{pH} 3.0$ & 3,200 \\
\hline & $\mathrm{pH} 4.0$ & 3,200 \\
\hline & pH 5.0 & 3,200 \\
\hline & pH 6.0 & 3,200 \\
\hline & $\mathrm{pH} 7.0$ & 3,200 \\
\hline & $\mathrm{pH} 8.0$ & 3,200 \\
\hline & pH 9.0 & 3,200 \\
\hline & PH 10.0 & 3,200 \\
\hline \multirow{7}{*}{$\begin{array}{l}\text { Organic } \\
\text { solvents }\end{array}$} & Ethanol & 3,200 \\
\hline & Methanol & 3,200 \\
\hline & Chloroform & 3,200 \\
\hline & Acetone & 1,600 \\
\hline & Acetonitrile & 1,600 \\
\hline & Hexane & 3,200 \\
\hline & Cyclohexane & 3,200 \\
\hline
\end{tabular}

slowly for $3 \mathrm{~h}$ (Fig. 3). During this period, the reduction in viable cell number was approximately $4.6 \mathrm{Log}$ scale $\left(4.5 \times 10^{3} \mathrm{CFU} / \mathrm{mL}\right)$ at $800 \mathrm{AU} / \mathrm{mL}, 4.3 \mathrm{Log}$ scale $(8.2 \times$ $\left.10^{3} \mathrm{CFU} / \mathrm{mL}\right)$ at $400 \mathrm{AU} / \mathrm{mL}$, and $2.8 \mathrm{Log}$ scale $\left(2.5 \times 10^{5}\right.$ $\mathrm{CFU} / \mathrm{mL}$ ) at $200 \mathrm{AU} / \mathrm{mL}$. The rapid decrease in the number of viable cells treated with bacteriocin suggests a mechanism based on bactericidal activity. The effectiveness of inhibition was in proportion to bacteriocin concentration. A similar mode of action has been observed in many other bacteriocins from LAB (Bhunia et al., 1991; Heo et al., 2007).

\section{Influence of $\mathrm{pH}$ and temperatures on cell growth and bacteriocin production}

When the $\mathrm{pH}$ of the culture was not controlled, bacteriocin production began toward the middle of the exponential growth phase, reached maximum levels $(2,400 \mathrm{AU} /$ $\mathrm{mL}$ ) during the stationary phase, and then rapidly declined (Fig. 4). The $\mathrm{pH}$ of the medium dropped from 6.5 to 4.1

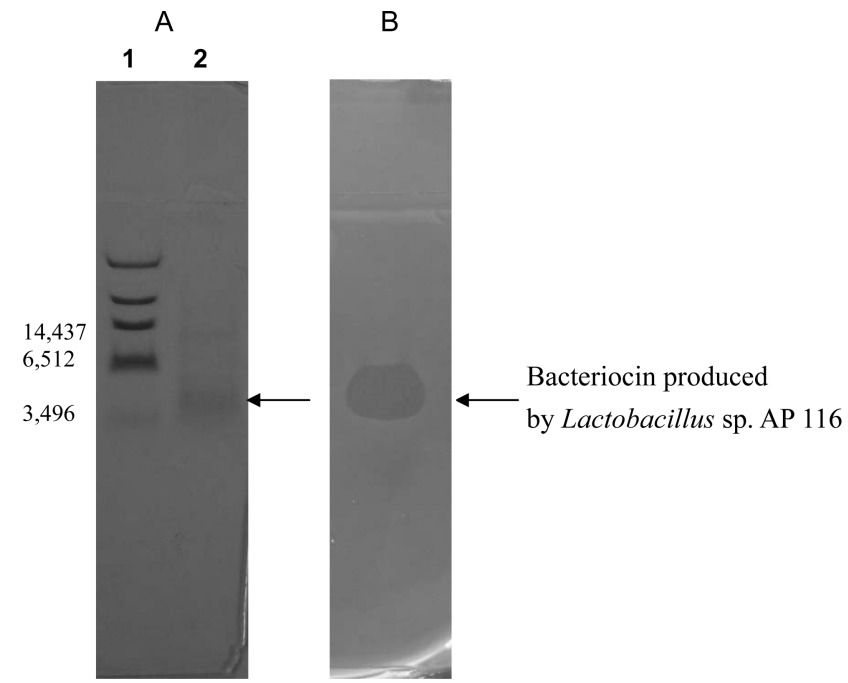

Fig. 2. SDS-PAGE and detection of antimicrobial activity of the crude bacteriocin from AP 116. (A) Gel stained with Coomassie brilliant blue G250: (lane 1) molecular weight standards, (lane 2) crude bacteriocin, and (B) gel overlaid with BHI soft agar inoculated with L. monocytogenes.

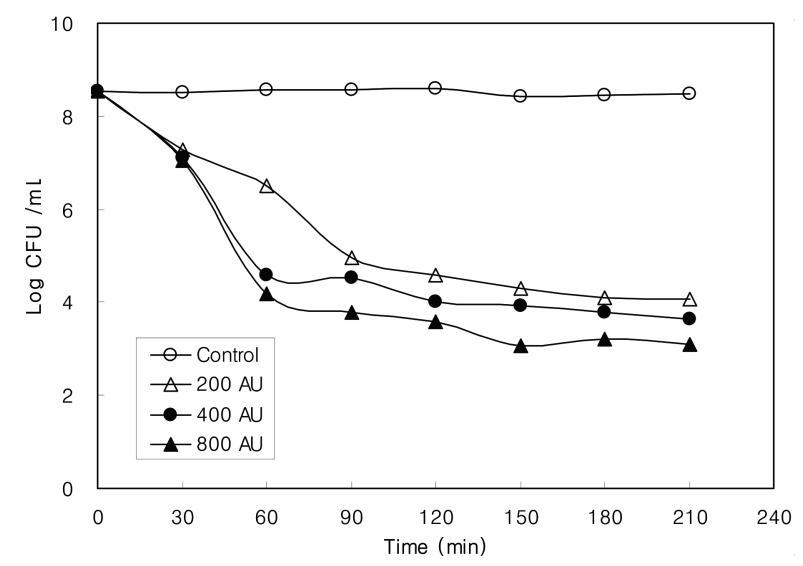

Fig. 3. Inhibitory action of AP 116 bacteriocin against $L$. monocytogenes incubated at $37^{\circ} \mathrm{C}$ in $10 \mathrm{mM}$ phosphate buffer.

during the 38-h incubation period. This pattern has been observed for other LAB bacteriocins (Aasen et al., 2000; Daba et al., 1991; Parente et al., 1994). Bacteriocins are often produced during growth phase and then decrease due to proteolytic degradation, protein aggregation, and adsorption (Parente and Ricciardi, 1994; Parente et al., 1994). Bacteriocin activities and cell counts were also determined at a constant $\mathrm{pH}$ of $5.0,6.0$, and 7.0 at $37^{\circ} \mathrm{C}$. Maximum bacteriocin production was at $\mathrm{pH} 6.0$ or less during fermentation, whereas bacteriocin activity was detected very low at $\mathrm{pH} 7.0$ at $37^{\circ} \mathrm{C}$. Optimal temperature for bacteriocin production and cell growth was at $34^{\circ} \mathrm{C}\left(6,400 \mathrm{AU} / \mathrm{mL}\right.$ and $3.8 \times 10^{9} \mathrm{CFU} / \mathrm{mL}$, respectively). 

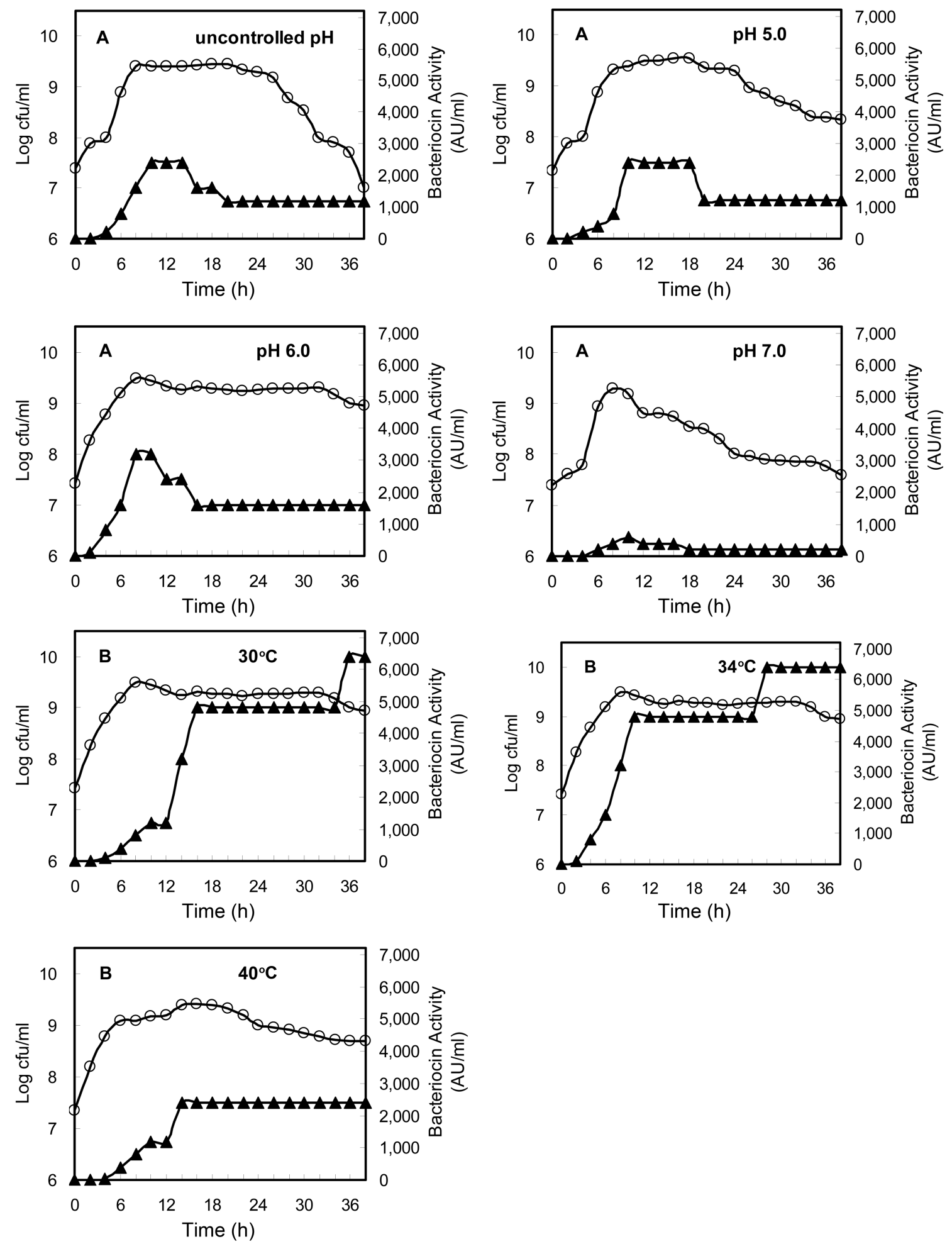

Fig. 4. Cell growth and bacteriocin production of Lactobacillus sp. AP 116 in MRS broth for (A) different pH at $37^{\circ} \mathrm{C}$ and (B) different temperatures at pH 6.0. (O) viable cell count; $(\Delta)$ bacteriocin activity.

\section{Evaluation of NO production and viability}

The immunostimulatory effect of the AP 116 strain was tested via NO production by in vitro culture experiments using murine peritoneal macrophages. The No production induced by both AP 116 and LGG were $1.78 \pm 0.06 \mu \mathrm{M} /$
$\mathrm{mL}$ and $1.67 \pm 0.18 \mu \mathrm{M} / \mathrm{mL}$, respectively, which were significantly different from that in the PBS control (Fig. 5). LGG has been known to have immunomodulatory effects by inducing immune cells to produce $\mathrm{NO}$ and inflammatory cytokines such as IL-12, IL-17, and TNF- $\alpha$ (Mileti et 


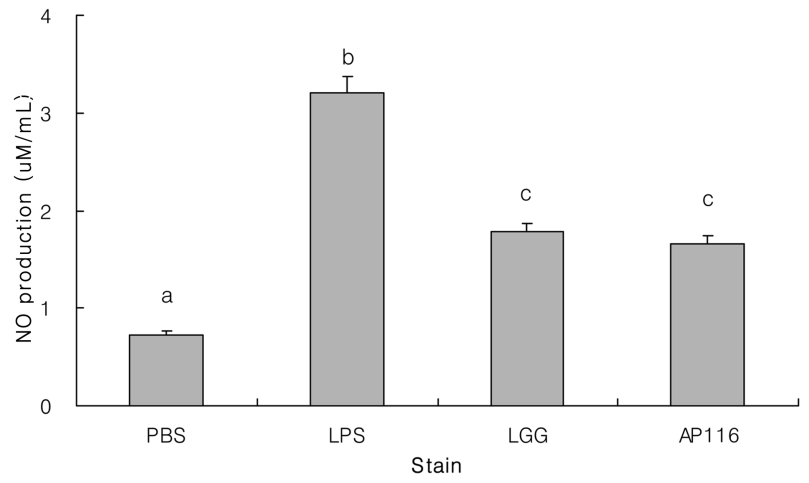

Fig. 5. Nitric oxide (NO) production by murine peritoneal macrophages induced by heat-killed $L$. rhamnosus GG (LGG) and Lactobacillus sp. AP 116. Murine peritoneal macrophages $\left(5 \times 10^{5}\right.$ cells $\left./ \mathrm{mL}\right)$ were stimulated with probiotics or PBS for $24 \mathrm{~h}$. Data are mean \pm SD values of triplicates. Different superscript letters $\left({ }^{\mathrm{a}, \mathrm{b}, \mathrm{c}}\right)$ indicate statistical differences as determined by ANOVA $(p<0.05)$.

al. 2009). The heat-killed AP 116 stimulated mouse peritoneal macrophages to increase the production of $\mathrm{NO}$ in a similar pattern to that of LGG. Resistance to low $\mathrm{pH}$ and bile salts are prerequisites for probiotics to survive and grow in the intestinal tract, as the beneficial effects of them can be expected when viable cells of these organisms are able to survive through the stomach and digestive system (Shin et al., 2008). The AP 116 strain was tolerant to $\mathrm{pH} 3.0$ and the residual counts were greater than $10^{6} \mathrm{CFU} / \mathrm{mL}$ after $2 \mathrm{~h}$ incubation, while showed reduced viability after being exposed to $\mathrm{pH} 2.0$ (Fig. 6A). This result is similar to previous studies, where Lactobacillus strains were viable even after being exposed to $\mathrm{pH}$ values of 2.5-4.0, but showed reduced viability at lower $\mathrm{pH}$ values (Mishra and Prasad, 2005). The selected strain was resistant to $0.5 \%$ bile salts (Fig. $6 \mathrm{~B}$ ). Bie salts and $\mathrm{pH}$ 3.0 had no effect on the AP 116.

The ability of probiotic bacteria to directly inhibit growth and proliferation of pathogenic microorganisms potentially confers the producer with a competitive advantage over other intestinal microbiota (Dahiya et al., 2006; Doron and Gorbach, 2006). This antimicrobial activity includes the production of antimicrobial factors such as bacteriocins, short chain fatty acid, nitric oxide and hydrogen peroxide. The bacteriocin produced by Lactobacillus sp. AP 116 isolated from pig intestine showed a wide spectrum of inhibitory activity against Gram-positive food spoilage bacteria and pathogens. Bacteriocin and bacteriocin-producing Lactobacillus sp. AP 116 could potentially be used in both food and feed industries as natural biopreservatives and for probiotic use in livestock.
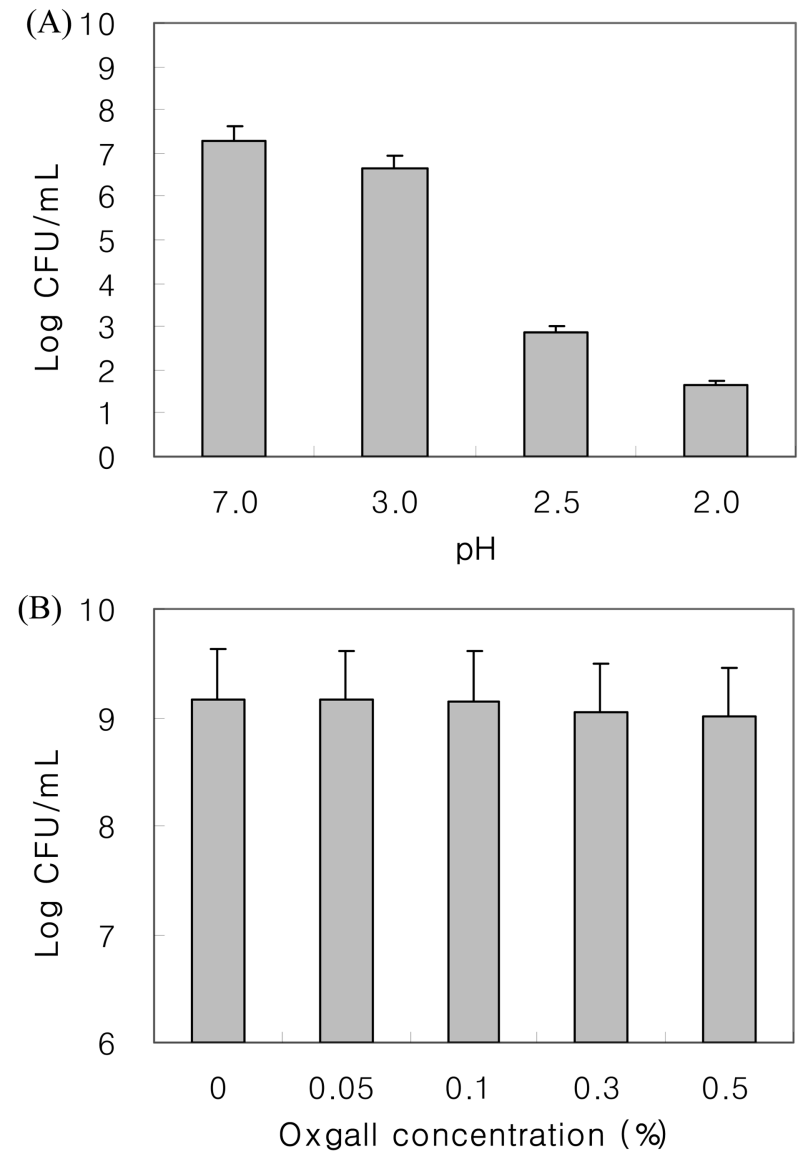

Fig. 6. Acid tolerance (A) and bile-salt resistance (B) of the AP 116 strain in sodium phosphate buffer at various pHs for $2 \mathrm{~h}$ and in MRS agar containing oxgall for 48 h, respectively.

\section{Acknowledgments}

This study was supported by research funds from the Small and Medium Business Administration, Republic of Korea.

\section{References}

1. Aasen, I. M., Moretro, T., Katla, T., Axelsson, L., and Storro, I. (2000) Influence of complex nutrients, temperature and $\mathrm{pH}$ on bacteriocin production by Lactobacillus sakei CCUG 42678. Appl. Microbiol. Biotechnol. 53, 159-166.

2. Bhunia, A. K., Johnson, M. C., Ray, B., and Kalchayamand, N. (1991) Mode of action of pediocin AcH from Pediococcus acidilactici $\mathrm{H}$ on sensitive bacterial strains. J. Appl. Bacteriol. 70, 25-33.

3. Byun, J. W., Kim, G. T., Bae, H. S., Baek, Y. J., and Lee, W. K. (2000) In vitro selection of lactic acid bacteria for probiotic use in pigs. Korea J. Vet. Res. 40, 701-706.

4. Callaway, T. R., Anderson, R. C., Edrington, T. S., Genovese, K. J., Harvey, R. B., Poole, T. L., and Nisbet, D. J. 
(2004) Recent pre-harvest supplementation strategies to reduce carriage and shedding of zoonotic enteric bacterial pathogens in food animals. Anim. Health Res. Rev. 5, 35-47.

5. Cleveland, J., Montville, T. J., Nes, I. F., and Chikindas, M. L. (2001) Bacteriocins: safe, natural antimicrobials for food preservation. Int. J. Food Microbiol. 71, 1-20.

6. Daba, H., Panadian, S., Gosselin, J. F., Simard, R., Huang, J., and Lacroix, C. (1991) Detection and activity of a bacteriocin produced by Leuconostoc mesenteroides. Appl. Environ. Microbiol. 57, 3450-3455.

7. Dahiya, J. P., Wilkie, D. C., Van Kessel, A. G., and Drew, M. D. (2006) Potential strategies for controlling necrotic enteritis in broiler chickens in post-antibiotic era. Anim. Feed Sci. Technol. 129, 60-88.

8. Damelin, L. H., Dykes, G. A., and Von Holy, A. (1995) Biodiversity of lactic acid bacteria from food-related ecosystems. Microbiol. 83, 13-22.

9. Diez-Gonzalez, F. (2007) Applications of bacteriocins in livestock. Curr. Issues Intestinal Microbiol. 8, 15-24.

10. Dibner, J. J. and Richards, J. D. (2005) Antibiotic growth promoters in agriculture: history and mode of action. Poultry Sci. 84, 634-643.

11. Doron, S. and Gorbach, S. L. (2006) Probiotics: their role in the treatment and prevention of disease. Expert. Rev. AntiInfect. Ther. 4, 261-275.

12. Du Toit, M., Franz, C. M. A. P., Dicks, L. M. T., and Holzapfel, W. H. (2000) Preliminary characterization of bacteriocins produced by Enterococcus faecium and Enterococcus faecalis isolated from pig faeces. J. Appl. Microbiol. 88, 482-494.

13. Gillor, O., Kirkup, B. C., and Riley, M. A. (2004) Colicins and microcins: the next generation antimicrobials. Adv. Appl. Microbiol. 54, 129-146.

14. Gonzalez, C. F. and Kunka, B. S. (1987) Plasmid-associated bacteriocin production and sucrose fermentation in Pediococcus acidilactici. Appl. Environ. Microb. 53, 2534-2538.

15. Heo, S., Lee, S. K., Lee, C. H., Min, S. G., Park, J. S., and Kim, H. Y. (2007) Morphological changes induced in Listeria monocytogenes $\mathrm{V} 7$ by a bacteriocin produced by Pediococcus acidilactici. J. Microbiol. Biotechnol. 17, 663-667.

16. Holt, J. G., Krieg, N. R., Sneath, P. H. A., Staley, J. T., and Williams, S. T. (1994) Bergey's Manual of Determinative Bacteriology. $9^{\text {th }}$ ed. Williams and Wilkins. Baltimore, USA

17. Joerger, R. D. (2003) Alternatives to antibiotics: bacteriocins, antimicrobial peptides and bacteriophages. Poultry Sci. 82, 640-647.

18. Jung, B. Y., Lim, H. S., and Kim, B. H. (2003) Prevalence of Listeria spp. in cecal contents of livestock. Kor. J. Vet. Publ. Hlth. 27, 41-46.

19. Kim, S. B., Lim, H. J., Lee, W. K., Hwang, I. G., Woo, G. J., and Ryu, S. R. (2006) PCR-based detection and molecular genotyping of enterotoxigenic Clostridium perfringens isolates from swine diarrhea in Korea. J. Microbiol. Biotechnol. 16, 291-294.
20. Kosin, B. and Rakshit, S. K. (2006) Microbial and processing criteria for production of probiotics: a review. Food Technol. Biotechnol. 44, 371-379.

21. Mayr-Harting, A., Hedges, A. J., and Berkeley, R. C. W. (1972) Methods for studying bacteriocins. In: Methods in Microbiology. Bergen, T. and Norris, J. R. (ed) Academic Press, London, pp. 315-422

22. Mileti, E., Matteoli, G., Iliev, I. D., and Rescigno, M. (2009) Comparison of the immunomodulatory properties of three probiotic strains of Lactobacilli using complex culture systems: prediction for in vivo efficacy. PLoS One 4, e7056.

23. Mishra, V. and Prasad, D. N. (2005) Application of in vitro methods for selection of Lactobacillus casei strains as potential probiotics. Int. J. Food Microbiol. 103, 109-115.

24. Oelschlaeger, T. A. (2010) Mechanisms of probiotic actions. Int. J. Med. Microbiol. 300, 57-62.

25. Parente, E. and Ricciardi, A. (1994) Influence of $\mathrm{pH}$ on the production of enterocin 1146 during batch fermentation. Lett. Appl. Microbiol. 19, 12-15.

26. Parente, E., Ricciardi, A., and Addario, G. (1994) Influence of $\mathrm{pH}$ on growth and bacteriocin production by Lactococcus lactis subsp. lactis 140 NWC during batch fermentation. Appl. Microbiol. Biotechnol. 41, 388-394.

27. Roselli, M., Finamore, A., Britti, M. S., Bosi, P., Oswald, I., and Mengheri, E. (2005) Alternatives to in-feed antibiotics in pigs: evaluation of probiotics, zinc or organic acids as protective agents for the intestinal mucosa. A comparison of in vitro and in vivo results. Anim. Res. 54, 203-218.

28. Shin M. S., Han, S. K., Ji, A. R., Kim, K. S., and Lee, W. K. (2008) Isolation and characterization of bacteriocin-producing bacteria from the gastrointestinal tract of broiler chickens for probiotic use. J. Appl. Microbiol. 105, 2203-2212.

29. Snyder, S. H. and Bredt, D. S. (1992) Biological roles of nitric oxide. Sci. Am. 266, 68-77.

30. Strompfová, V., Marciòáková, M., Simonová, M., Gancarèíková, S., Jonecová, Z., Sciranková, L., Košèová, J., Buleca, V., Ėobanová, K., and Lauková, A. (2006) Enterococcus faecium EK13-an enterocin A-producing strain with probiotic character and its effect in piglets. Anaerobe 12, 242-248.

31. Thévenot, D., Dernburg, A., and Vernozy-Rozand, C. (2006) An updated review of Listeria monocytogenes in the pork meat industry and its products. J. Appl. Microbiol. 101, 7-17.

32. Warriner, K., Aldsworth, T. G., Kaur, S., and Dodd, C. E. R. (2002) Cross-contamination of carcasses and equipment during pork processing. J. Appl. Microbiol. 93, 169-177.

33. Yang, R., Johnson, M. C., and Ray, B. (1992) Novel method to extract large amounts of bacteriocins from lactic acid bacteria. Appl. Environ. Microb. 58, 3355-3359.

34. Zhang, X., Goncalves, R., and Mosser, D. M. (2008) The isolation and characterization of murine macrophages. Curr. Protoc. Immunol. Chapter 14, Unit 14.1.

(Received 2011.11.21/Revised 1st 2011.12.15, 2nd 2012.1.3/ Accepted 2012.1.4) 